\title{
HOGYAN RONTHATJA EL AZ ÁLLAM AZ INNOVÁCIÓFINANSZÍROZÁST?'
}

\author{
Berlinger Edina ${ }^{2}$
}

Kettős erkölcsi kockázatot és pozitív externáliákat tartalmazó, fix beruházásos modellben vizsgáljuk, milyen hatása van az állami támogatásnak a vállalkozó és a kockázati tőkés viselkedésére. Azt kapjuk, hogy a beruházási támogatás és a sikerdíj javítja az ösztönzőket, oldja a hitelszűkét, így katalizálja a magánfinanszírozást, ami alátámasztja az állami és a hibrid kockázatitőke-rendszerek népszerűségét. Ezeknek azonban az a fö hátránya, hogy a vállalkozót a saját befektetésének a minimalizálására és a lehető legnagyobb állami támogatás lehívására ösztönzik. Könnyen lehet, hogy az állami forrásokat olyan vállalkozók kapják, akik mindenképpen megvalósították volna a projektjüket, így a támogatás csak az állami kiadásokat (és a magánhasznokat) növeli számottevő jóléti hatás nélkül, fontosabb területektől vonva el a finanszírozást. Bebizonyítjuk azt is, hogy az állami garanciavállalás egyértelmüen torz ösztönzőket teremt, ezért alkalmazása modellünk alapján nem indokolható.

JEL-kódok: $\mathrm{D}_{21}, \mathrm{G}_{3} 8, \mathrm{H}_{32}, \mathrm{H}_{5} \mathrm{O}, \mathrm{O}_{3} 8$

Kulcsszavak: innovációfinanszírozás, kockázati tőke, állami támogatás, erkölcsi kockázat

\section{BEVEZETÖ}

Az innovációs folyamat során megkülönböztethetjük az ötletgazdát - vagy más néven feltalálót - és a vállalkozót: előbbinek még csak egy újító ötlete van, utóbbinak azonban már szabadalma, terméke, projektje, sőt akár formális vállalkozása is. Stiglitz-Greenwald (2014) az inventor és innovátor kifejezésekkel utal erre a különbségre. Az első, innovációkkal kapcsolatosan felmerülö gazdaságpolitikai kérdés az, hogy az invenciót vagy az innovációt érdemes-e jobban támogatni a

1 Köszönetnyilvánitás: A kutatás a Magyar Tudományos Akadémia Bolyai János ösztöndíja és az Emberi Erőforrások Minisztériuma ÚNKP-18-4 kódszámú Új Nemzeti Kiválóság Programja támogatásával készült.

2 Berlinger Edina a Budapesti Corvinus Egyetem Befektetések és Vállalati Pénzügy Tanszékének tanszékvezető egyetemi tanára. 
rendelkezésre álló eszközökkel. Stiglitz-Greenwald (2014, 6. fejezet, D függelék) bemutatja, hogy a két terület kölcsönösen hat egymásra: az innovátorok egyrészt kisajátítják (például szabadalmak révén) a mindenki számára elérhető, közös tudást, másrészt azonban ipari célú kutatási projektek finanszírozásával növelik is azt. Ezt a dinamikus egymásra hatást egy halastó példáján elemzik, ahol a halak az új ötletek, a halászok az innovátorok, akik a profitjukból időnként költenek a halak visszatelepítésére (invencióra) is. Stiglitz-Greenwald (2014) bebizonyítja, hogy a halászoknak nyújtott külső támogatás végső soron csökkenti a halállományt, és így olyan egyensúlyi állapotot hoz létre, amelyben a halászok profitja is alacsonyabb lesz. Lefordítva ezt az innováció nyelvére: könnyen lehet, hogy az innovációs támogatások végső soron elsorvasztják az alapkutatást, illetve kimerítik a közös tudás „halastavát”, és így a beavatkozás hosszú távon éppen ellentétes hatást ér el; alacsonyabb lesz az innováció szintje és a gazdasági növekedés is. Közgazdasági közhely, hogy a pozitív externáliákkal (tovagyürüző társadalmi hatásokkal) bíró javak esetében - mint amilyen az alapkutatás is - várhatóan az alultermelés lesz a jellemző, ha mindent a piacra hagyunk. Mindezek alapján úgy tünik, hogy az államnak több feladata van az alapkutatás támogatásában és finanszírozásában, mint az innováció direkt ösztönzésében. Stiglitz-Greenwald (2014) a szellemi tulajdonjogok rendszerének radikális újragondolását és az exporttámogatást jelöli meg az innovációösztönzés legfőbb eszközeiként (Berlinger, 2017). Mazzucato (2012) kiterjeszti a „vállalkozó állam” koncepcióját, és mindent átfogó, stratégiai keretrendszerben gondolkodik az állam szerepéről az innováció ösztönzésében. A továbbiakban ezt a vitát félretesszük, és kizárólag azt vizsgáljuk, hogy az innováció direkt állami támogatása milyen hatást gyakorol a projektek elindítására és sikerére.

A korai szakaszban lévő innovatív vállalkozások fő jellemzői a magas szintű kockázat és bizonytalanság, a kiélezett információs aszimmetria (a vállalkozó jobban ismeri a projektet és a saját erőfeszítését, mint a külső szereplők), illetve a jelentős pozitív externáliák. Ezek a jellemzők együttesen jelentősen megnehezítik a finanszírozást. Egyfelől az információs aszimmetria negatív következményei, az erkölcsi kockázat és a kontraszelekció fokozottan jelentkeznek, tehát kiemelt figyelmet kell fordítani a szerződéses ösztönzők, illetve a szűrési és ellenőrzési rendszerek kialakítására (Jáki és szerzőtársai, 2017). Másfelől a kockázatkezelési szempontok általában homlokegyenest szembemennek az ösztönzési szempontokkal, elég csak arra gondolni, hogy a túlzott biztonság elkényelmesít (Pauly, 1968).

Tovább bonyolítja az átváltásokat (trade-off), ha az állam, az EU vagy egyéb külső támogató a pozitív externáliák érdekében beavatkozik, hiszen a támogatás hatására megváltozhatnak a kockázatok és az ösztönzők is. Ha mindezekhez hozzávesszük az innovációkat övező, nagyfokú bizonytalanságot, akkor végképp 
felkészülhetünk arra, hogy a kockázati tőke piaca nem lesz sem teljes (nem lehet minden jövőbeli eseményre biztosítást kötni), sem tökéletes (jelentősek lehetnek a súrlódások például a tranzakciós és ügynökköltségek miatt), sem pedig hatékony (jelentős félreárazások fordulhatnak elö). Pedig Kornai (2010) is hangsúlyozza, hogy az innovációk elterjedésének alapvető feltétele a rugalmas és elérhető finanszírozás (lásd még Berlinger, 2017). Ebből viszont az is következik, hogy a mechanizmus gondos kialakítása nagy értéket teremthet.

A gyakorlatban összetett szerződések, szürési mechanizmusok és monitoringrendszerek fejlődtek ki a fenti problémák kezelésére vagy legalább csökkentésére (Karsai, 2013). Gyakran alkalmazott konstrukció például a szakaszos finanszírozás és az átváltható kötvény, illetve jellemző, hogy a külső finanszírozó rendkívül erős kontrolljogokat kap (Aman-Lovas, 2015; Lovas és szerzőtársai, 2015). Mindezek mellett a kockázati tőkés (aktív) finanszírozása főként a tekintetben különbözik a klasszikus banki (passzív) finanszírozástól, hogy a kockázati tőkés maga is tevőlegesen részt vállal a projekt megvalósításában, tanácsot ad, átszervez, kapcsolatokat szerez stb., és ezzel maga is hozzájárul a projekt sikeréhez (vagy kudarcához). Az optimális finanszírozási konstrukciótól tehát azt várjuk el, hogy ne csak a vállalkozót ösztönözze megfelelő erőfeszítésre, de a kockázati tőkést is, azaz mindkét oldalról kezelje az erkölcsi kockázatot.

Ebben a cikkben az egyszerüség kedvéért félretesszük a kockázatkezelésből, a bizonytalanságból, a kontraszelekcióból, a tranzakciós költségekből stb. adódó problémákat (feltesszük, hogy a szereplők kockázatsemlegesek, minden döntési paraméter közismert, a vállalkozók és a finanszírozók is homogének, nincsenek tranzakciós költségek stb.), és csak arra koncentrálunk, hogy az állami támogatás hogyan hat az egyszeres és a kétszeres erkölcsi kockázatra a kockázatitőkefinanszírozás során. A kétszeres erkölcsi kockázatot egy olyan modellben vizsgáljuk, ahol a vállalkozó és a finanszírozó végletesen egymásra utalt: a projektnek ugyanis csak akkor pozitív a nettó jelenértéke, ha mind a vállalkozó, mind a finanszírozó teljes erőbedobással dolgozik a sikerért.

Az elméleti szakirodalomban széleskörűen elterjedt az a meggyőződés, hogy az állami támogatás elrontja az ösztönzőket, de egyúttal segíti a pozitív externáliák létrejöttét (növeli a rendelkezésre álló szabad forrásokat), a nettó jólétnövekedés pedig végeredményben attól függ, hogy melyik hatás az erősebb (Lovas-Mile, 2015). Az empirikus tapasztalatokat részletező szakirodalmi eredmények vegyesek (Becsky-Nagy-Fazekas, 2017; Karsai, 2015 és 2018; Jáki-Molnár, 2017b), de a szakmai közvélekedés erősen hajlik arra, hogy Magyarországon a negatív hatások felülmúlják a pozitívakat (Kállay, 2014).

Vizsgálatunk meglepő eredménye, hogy a modell feltételei mellett, ha a vállalkozó megfelelően motivált, akkor automatikusan a kockázati tőkés is az, tehát az egyszeres és a kétszeres erkölcsi kockázat kezelése lényegében nem különbö- 
zik egymástól. Ez az érdekegyezés csak az állami garancia esetén csúszik szét. Egyébként is nagyon számít, hogy az állam hogyan választja meg a támogatási formát és a támogatás mértékét. A beruházási támogatás és a sikerdíj, ha jól csinálják, értéket teremt, míg a garanciavállalás (vagy a vállalkozás ki- vagy megmentése) csak rombolja az ösztönzőket, ezért annak optimális mértéke a modellben nulla még akkor is, ha a pozitív externáliák nagyon jelentősek. A modellben tehát előáll a puha költségvetési korlát jelensége (Kornai és szerzőtársai, 2003), de annak keretein belül nem kapunk magyarázatot arra, hogy az államnak miért éri meg ebben a formában beavatkozni, annak tehát a modellen kívüli okai lehetnek.

A tanulmány 2. pontjában bemutatjuk az egyszeres és kétszeres erkölcsi kockázat melletti optimális magánfinanszírozási szerződést. A 3. pontban már belép az állam is beruházási támogatás, sikerdíj vagy kimentés (garanciavállalás) formájában, és megvizsgáljuk a háromszereplős optimum jellemzőit, végül a 4. pontban vonjuk le a következtetéseinket.

\section{MAGÁNFINANSZÍROZÁS}

\subsection{Egyszeres erkölcsi kockázat}

Az erkölcsi kockázat elemzéséhez Tirole (2006, 115. o.) egyszeres erkölcsi kockázat melletti magánfinanszírozásról szóló alapmodelljének különböző kiegészítéseit használjuk. Feltételezzük, hogy a beruházás fix méretű, se nem bővíthető, se nem szűkíthető. Ez a modell alkalmasabb az egyedi, innovatív projektek leírására, mint az állandó skálahozadékot feltételező, változó beruházásos modell (lásd pl. Csóka és szerzőtársai, 2013; Berlinger és szerzőtársai, 2015 és 2017). Az állandó skálahozadék inkább az érettebb iparágakra jellemző, például, ha azok nemzetközi terjeszkedését akarjuk modellezni. A vállalkozónak van tehát egy projektje, amelyhez I nagyságú kezdeti beruházásra van szükség. A vállalkozónak azonban csak ennél kevesebb kezdeti tőke (befektethető eszköz), $A$ áll a rendelkezésére. A hiányzó $(I-A)$ nagyságú tőkét külső forrásból kell megszereznie vagy le kell mondania a projektről és annak minden hasznáról.

A projekt egyperiódusú ( $t=0$-tól $t=1$-ig tart), és két kimenete van: sikerül $p$ valószínűséggel vagy kudarcot vall $1-p$ valószínűséggel. A projektnek siker esetén $R>0$, kudarc esetén nulla nagyságú ellenőrizhető pénzáramlása van (lásd 1. ábra). 


\section{1. ábra}

\section{A projekt teljes pénzáramlása}

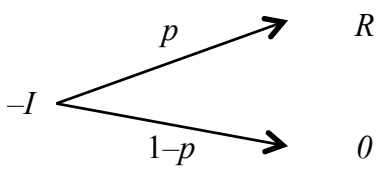

0.

1.

Forrás: Tirole $(2006,115$. o.)

Egyszeres erkölcsi kockázat esetén a projekt sikerének valószínűsége $(p)$ kizárólag a vállalkozó viselkedésétől függ. Ha a vállalkozó mindent megtesz a projekt sikeréért, azaz ha a vállalkozó jól viselkedik, akkor a siker valószínűsége magas: $p=p_{H}$, míg alacsony erőfeszítés mellett a siker valószínüsége alacsony: $p=p_{L}$ $\left(p_{H}>p_{L}\right)$ (Tirole, 2006, 115. o.).

A rossz viselkedés több formában is megjelenhet. Ezek egy része legális, például ha a vállalkozó kényelemből nem tesz meg mindent a projekt sikeréért, azaz lóg (shirking); ha olyan projektet választ, ami vagy összefügg a kedvenc időtöltésével (pet project), vagy amellyel nélkülözhetetlenné teszi magát, és ezzel bebetonozza a saját pozícióját (entrenchment), vagy ami több mellékjövedelmet (perks) nyújt a számára, vagy kedvező lehetőséget teremt a barátok és rokonok „megsegítésére”. Ez utóbbi elem már átvezet az illegális tevékenységekhez, például a korrupcióhoz, a csaláshoz és a lopáshoz.

A rossz viselkedés azért lehet vonzó a vállalkozó számára, mert abból $B>0$ magánhaszna keletkezik, amire másik oldalról úgy is tekinthetünk, mint a jó viselkedés pénzben kifejezett, személyes költségére.

A modellben az erkölcsi kockázat abból adódik, hogy a finanszírozó nem tudja megfigyelni, a vállalkozó jól viselkedik-e vagy sem. Ez tehát az információs aszimmetria speciális esete, ahol a finanszírozó és a vállalkozó kapcsolata egy speciális megbízó-ügynök viszonnyal írható le. Ha a vállalkozó, vagyis az ügynök nincs megfelelően ösztönözve, akkor a saját érdekét tartja szem előtt, és nem a megbízóét. Az ún. erkölcsi kockázat tehát racionális haszonmaximalizálásból és nem valamiféle rossz erkölcsből fakad (Pauly, 1968). Feltesszük, hogy a projekt magánhaszna (externáliák nélkül), vagyis az NPV-je (net present value, nettó jelenérték) csak akkor pozitív, ha a jó viselkedés biztosított:

$$
\begin{gathered}
N P V_{j o ́} \text { viselkedés } \\
\quad p_{H} R-I>0>p_{L} R-I+B
\end{gathered}
$$


Megjegyezzük, hogy a projekt a vállalkozó rossz viselkedése esetén is sikerülhet - csak kisebb valószínüséggel -, a projekt sikere tehát nemcsak a vállalkozón, de a körülményeken, a véletlenen is múlik.

Az egyszerüség kedvéért az alapmodellhez (Tirole, 2006, 115. o.) hasonlóan feltesszük, hogy a külső finanszírozó által elvárt hozam nulla (nincs időpreferencia, a szereplők kockázatsemlegesek és tökéletes verseny van a finanszírozók piacán), illetve a vállalkozó korlátozott felelősséggel bír, tehát az $A$ kezdeti befektetése után további befizetésekre nem kötelezhető. A vállalkozóé az egyedi, nyereséggel kecsegtető projekt, a finanszírozók azonban sokan vannak, könnyen helyettesíthetők, az ő piacukon tökéletes a verseny. Az érték tehát a vállalkozói oldalon keletkezik. A vállalkozó kínálja föl a szerződést, amit a finanszírozók egymásra licitálva igyekeznek megszerezni.

A magánfinanszírozást felfoghatjuk olyan szerződéstervezési feladatnak, melynek során két kérdésre kell válaszolni:

1. Kap-e finanszírozást a projekt?

2. Hogyan osztozik a profiton a vállalkozó és a finanszírozó?

Belátható, hogy kudarc esetén a felek nem fizetnek egymásnak semmit. A második kérdés tehát valójában úgy fogalmazható át, hogy siker esetén milyen összegben részesüljön az $R$ bevételből a vállalkozó $\left(R_{e}\right)$, illetve a finanszírozó $\left(R_{i}\right)$. A szerződésnek olyannak kell lennie, hogy az ösztönözze a vállalkozót a jó viselkedésre. Az alábbi egyenlőtlenség azt a feltételt fogalmazza meg, hogy jó viselkedés esetén legyen magasabb a vállalkozó várható bevétele, mint rossz viselkedés esetén (ösztönzési korlát):

$p_{H} R_{e} \geq p_{L} R_{e}+B$

Ezt átrendezve és felhasználva a $\Delta p=p_{H}-p_{L}$ összefüggést, kapjuk, hogy

$$
R_{e} \geq \frac{B}{\Delta p}
$$

Ebből következik, hogy $\left(R_{e}\right)$-nek legalább $\frac{B}{\Delta p}$ nagyságúnak kell lennie, különben a vállalkozó nem lenne eléggé motivált. A vállalkozó tehát nem ígérhet többet (jelenértéken) a finanszírozónak, mint $p_{H}\left(R-\frac{B}{\Delta p}\right)$, amit Tirole (2006) elígérhetö jövedelemnek (pledgeable income) nevez, és $\rho$-val jelöl.

Másrészt azt is biztosítani kell, hogy a finanszírozónak megérje a részvétel. Mivel a finanszírozó kockázatsemleges és az elvárt hozama nulla, neki elég, ha a várható bevétele eléri a befektetésének nagyságát (részvételi korlát): 
$p_{H} R_{i} \geq I-A$

azaz

$R_{i} \geq \frac{I-A}{p_{H}}$

A (2) ösztönzési és a (3) részvételi korlátokból következik (felhasználva az $\mathrm{R}=R_{e}$ $+R_{i}$ összefüggést), hogy a projekt csak akkor kap finanszírozást, ha a vállalkozó elegendő, legalább $\bar{A}$ saját tőkével rendelkezik (a finanszírozás szükséges feltétele):

$A \geq \bar{A}=p_{H} \frac{B}{\Delta p}-\left(p_{H} R-I\right)=I-p_{H}\left(R-\frac{B}{\Delta p}\right)=I-\rho$

A (4) összefüggést úgy lehet értelmezni, hogy a projekt NPV-jének $\left(p_{H} R-I\right)$ és a vállalkozó $(A)$ kezdőtőkéjének együtt elegendőnek kell lennie a $p_{H} \frac{B}{\Delta p}$ ügynökköltségre (agency cost). De úgy is fogalmazhatunk, hogy a kezdőtőkének és az elígérhető jövedelemnek együtt elégnek kell lennie a befektetéshez.

Vegyük észre, hogy (4) egyben elégséges feltétele is a finanszírozásnak, mivel feltettük, hogy a finanszírozók versenye tökéletes, így (3) egyenlőséggel teljesül. Mivel a paraméterek és a döntési szabályok mindkét fél számára ismertek, és a vállalkozó ajánlja a szerződést, ezért a vállalkozó csak a minimálisan szükséges $A=\bar{A}$ tőkét fogja bevallani, tehát optimumban a vállalkozói saját tőke:

$$
A^{o p t}=I-\rho
$$

A fentiekben megfogalmazott 1. számú, „lenni vagy nem lenni” típusú kérdésre tehát az a válasz: az erkölcsi kockázat mellett előfordulhat, hogy nagyon magas NPV-jű projektek sem kapnak finanszírozást, ha a vállalkozónak nincs elegendő tökéje. Különösen igaz ez, ha potenciálisan nagy a vállalkozónak a rossz viselkedésből származó magánhaszna $(B)$, illetve, ha a jó viselkedés csak kismértékben növeli meg a siker valószínüséget $(\Delta p)$.

A 2., „osztozkodós” kérdésre pedig az a válasz, hogy a projekt minden haszna (NPV-je) a vállalkozónál marad, amihez azonban csak a projekt sikere esetén tud hozzájutni, ez ösztönzi öt erőfeszítésre. A finanszírozó csak éppen akkora összeget kap, hogy várható értékben visszakapja a befektetését (osztozkodási szabály):

$$
\begin{gathered}
R_{e}=R-R_{i} \\
R_{i}=\frac{I-A}{p_{H}}
\end{gathered}
$$




\subsection{Kétszeres erkölcsi kockázat}

Az előző pontban tárgyalt egyszeres erkölcsi kockázat modelljét többféleképpen is általánosíthatjuk a kettős erkölcsi kockázat esetére, amikor a finanszírozó nem bank, hanem kockázati tőkés, aki (jó esetben) maga is aktívan hozzájárul a projekt sikeréhez. Ebben a cikkben azt feltételezzük, hogy a vállalkozó és a finanszírozó erőfeszítése tökéletesen kiegészíti egymást. A valóságban a vállalkozó és a finanszírozó bizonyos fokig helyettesítheti is egymást (lásd például Tirole, 2006, 364. o.), de az itt bemutatott modell tükrözi leginkább a két fél egymásrautaltságát.

Tökéletes kiegészítést feltételezve, egyformán szükség van a vállalkozó és a kockázati tőkés erőfeszítésére a magasabb sikervalószínűség, $p_{H}$ eléréséhez, és ha bármelyikük is rosszul viselkedik, a sikervalószínüség $p_{L}$-re csökken, az egyik szereplő erőfeszítése tehát egyáltalán nem helyettesíti a másik szereplő erőfeszítését.

Továbbra is feltesszük, hogy számít a szereplők viselkedése, azaz van erkölcsi kockázat. Hogy együttesen se érje meg nekik a rossz viselkedés, (1) módosított verziójára van szükség:

$p_{H} R-I>0>p_{L} R-I+B+C$

Látható, hogy (7) szigorúbb, mint (1), tehát egy szűkebb halmazon optimalizálunk, és ami (7) mellett igaz, az (1) esetén is teljesül.

Most is megköveteljük a vállalkozó ösztönzési korlátját (2) és a finanszírozó részvételi korlátját (3). Emellett új feltételként megjelenik a kockázati tőkés ösztönzési korlátja is, amit a vállalkozó ösztönzési korlátjához hasonlóan írhatunk fel:

$$
R_{i} \geq \frac{C}{\Delta p}
$$

ahol $C$-vel jelöljük a kockázati tőkés magánhasznát (más szóval az erőfeszítéseinek a költségét $(C>0)$.

Belátjuk, hogy az egyszeres erkölcsi kockázat mellett (2)-ből és (3)-ból adódó (5) optimális vállalkozói kezdőtőke most is optimális. Ehhez csak azt kell megmutatni, hogy (5) teljesíti a (8) korlátot is. Ezt egyszerü számolással kapjuk a (7)-ből adódó

$$
\Delta p R>B+C
$$

egyenlőtlenség felhasználásával. 
Meglepő eredmény tehát, hogy a kétszeres erkölcsi kockázat modelljében, ha a vállalkozó és a finanszírozó erőfeszítése tökéletesen kiegészíti egymást, akkor az optimális finanszírozási szerződés megegyezik az egyszeres erkölcsi kockázat melletti szerződéssel. Más megfogalmazásban, az aktív kockázati tőkés megjelenése (a passzív bank helyett) nem befolyásolja a vállalkozó részéről a projekthez szükséges kezdőtőke mennyiségét, azaz most is $\bar{A}$ nagyságú tőkével kell rendelkeznie a finanszírozáshoz.

Megjegyezzük, hogy ebben a modellben kiemelt jelentőséggel bír a másik magánhasznának ( $B$ és $C$ ), tehát a típusának a pontos ismerete (közismert tudás). Ha azonban információs aszimmetria lép föl, azaz mindenki csak a saját potenciális magánhasznát ismeri, akkor az nemcsak erkölcsi kockázatot, de kontraszelekciós veszélyt (is) jelent, amit kifinomult szürési (screening) és jelzési (signaling) technikákkal lehet kezelni (Lovas, 2015), és e tekintetben jelentős szerepet kaphat az is, hogy vállalkozó mennyi kezdőtőkét ajánl föl, és a finanszírozó milyen vállalkozói kezdőtőke mellett hajlandó beszállni a finanszírozásba.

\section{3. Állami TÁMOGATÁS}

Ebben a fejezetben azt vizsgáljuk meg, hogy mi történik, ha a vállalkozó a projekt elindításához szükséges külső forrást magánfinanszírozás mellett vagy helyett (részben vagy egészben) állami támogatásból is megszerezheti. (A hibrid, azaz magán- és állami tőkét kombináló kockázati tőkealapok működéséről lásd Lovas-Mile, 2015; Lovas-Ri2, 2016; Jáki-Molnár, 2017a; Karsai, 2018).

Tirole $(2006,115$. o.) alapmodelljébe új elemként bevezetjük a társadalmi továbbgyürüző hatásokat, azaz pozitív externáliákat $(E>0)$, amelyek a projekt sikerétől vagy kudarcától függetlenül mindenképpen jelentkeznek például tudástranszfer, növekvő foglalkoztatás vagy növekvő beszállítói aktivitás formájában (Berlinger és szerzőtársai, 2015 és 2017). Felételezzük, hogy az externáliák explicit módon, pénzben kifejezett bevételként jelennek meg az állami költségvetésben a $t=1$ időpontban. A magánszereplők természetesen maguktól nem veszik figyelembe ezeket a külső hatásokat, ezek csak az államnak fontosak. Látni fogjuk, hogy a pozitív externáliák miatt az államnak érdeke füződhet a projekt megvalósításához akkor is, ha a kockázatitőke-piac nem működik megfelelően, vagy ha a vállalkozó kezdeti tőkehiánya miatt a magánfinanszírozás nem elérhető.

Az állami támogatás jelenértéke, $\tilde{S}$ nem lehet több, mint az externáliákból származó költségvetési bevétel, $E$ (költségvetési korlát):

$\tilde{S} \leq E$ 
Az állami támogatás egyösszegü, vissza nem térítendő és formáját tekintve háromféle lehet: vagy a projekt elején kapja a vállalkozó (beruházási támogatás), vagy a végén siker esetén (sikerdij), vagy a végén kudarc esetén (kimentés vagy más néven garanciavállalás). Továbbra is az 1 . ábrának megfelelő projektet vizsgáljuk, amelyhez három lehetséges állapot kapcsolódik: a jelen pillanat, illetve a két lehetséges jövőbeli állapot. A vizsgált támogatási formák megfelelnek az ezekhez az állapotokhoz tartozó ún. Arrow-Debreu-értékpapíroknak, a bonyolultabb támogatási konstrukciók pedig ezekből mint építőkockákból összerakhatók.

A következő pontokban bemutatandó modellekben három szereplő van: a vállalkozó, a magánfinanszírozó és az állam. Az erkölcsi kockázat kétszeres lehet, ami a vállalkozó és/vagy a finanszírozó oldalán jelentkezhet, ugyanúgy, mint a 2.2 modellekben. Most is feltesszük (7)-et, azaz hogy az NPV szempontjából számít a vállalkozó és a finanszírozó viselkedése.

Az állam oldalán azért nem merül fel az erkölcsi kockázat, mert az állam passzívan adja a támogatást, utána nem vesz részt a megvalósításban, az ő erőfeszítése tehát nem szükséges a sikerhez. Természetesen a valóságban az állami támogatás odaítélésénél és a kondíciók meghatározásakor lehetnek hatékonytalanságok és visszaélések, de a modellezés során ezektől eltekintünk, és abból indulunk ki, hogy az állam optimálisan avatkozik be, tehát a projekt össztársadalmi hasznosságát maximalizálja. A projekt $U$ össztársadalmi hasznosságát (jelenértéken) úgy számítjuk, hogy a nettó jelenértékhez hozzáadjuk az externáliákat és levonjuk az állami támogatás jelenértékét:

$U=N P V+(E-\tilde{S})=$ vállalkozó haszna + költségvetés haszna

Ez egy nagyon erős állítás, egyrészt mert az államnak egyformán fontos a magánérdek (NPV) és a társadalmi többlet $(E-\widetilde{S})$, másrészt azért, mert eltekintünk a valóságban nagyon is gyakran jelentkező állami kudarcoktól, például attól, hogy az államapparátus is önérdekkövető és széthúzó egyénekből áll; nincs minden szükséges információ birtokában, és a szigorú, pénzben mért gazdasági előnyökön túl sok más szempontot is figyelembe vesz a gazdaságpolitika alakításakor. Az állam az alábbi modellekben tehát végtelenül jószándékú, következetes, mindentudó és a (11) szerint meghatározott, viszonylag szűken definiált cél érdekében a (10) korlát mellett optimalizál. Ezekre az egyszerüsítő feltételekre azért van szükség, hogy kizárólag a vállalkozó és a finanszírozó viselkedésére és az abból származó erkölcsi kockázatra tudjunk koncentrálni.

Az alábbiakban a 2.2 pontban bemutatott kettős erkölcsi kockázatot és csak magánszereplöket tartalmazó modellbe egyenként bevezetjük a különböző állami támogatási formákat (beruházási támogatás, sikerdij, kimentés), ami tehát három 
különböző esetet jelent. Feltesszük, hogy az állami támogatásra közvetlenül a vállalkozó pályázik.

A modellekben az állami támogatás optimális nagyságának meghatározásakor többféle küszöbértékre is figyelemmel kell lenni:

- 0 az alsó korlát, ami kizárja azokat a helyzeteket, amikor az állam negatív támogatást ad, például megadóztatja az innovatív projektet.

- $\quad S^{\text {max }}$ az a felső korlát, aminél többet nem adhat az állam a költségvetési korlátja miatt.

- $\quad \bar{S}$ az a küszöbérték, ami mellett a projekt még éppen kap magánfinanszírozást, ez egyben a vállalkozó jó viselkedésének küszöbértéke is.

Általános esetben a fent felsorolt küszöbértékek relatív elhelyezkedésétől függ az optimális állami támogatás:

$$
S^{o p t}=f\left(0, S^{\max }, \bar{S}\right)
$$

Az $S^{\text {opt }}$ konkrét értékét úgy határozzuk meg, hogy először egy táblázatban öszszegezzük az adott helyzetben releváns küszöbértékeket, majd értelmezzük a küszöbértékeket, megállapítjuk a korlátok egymáshoz való viszonyát és elemezzük a lehetséges helyzeteket, végül (11) szellemében meghatározzuk az optimumot.

\subsection{Beruházási támogatás}

Beruházási támogatás esetén változatlan formában érvényben van a vállalkozó (2) ösztönzési feltétele. Módosul azonban a magánfinanszírozó (3) részvételi korlátja, hiszen az állami támogatás miatt kevesebb magánfinanszírozás bevonására van szükség a projekt indításához:

$$
p_{H} R_{i} \geq I-A-S
$$

A finanszírozó (8) ösztönzési korlátja nem változik. Mivel verseny van a finanszírozók között, (13) egyenlőségre teljesül. Ebből $R_{i}$-t kifejezve és (2)-be helyettesítve megkapjuk a finanszírozás szükséges feltételét beruházási támogatás mellett:

$$
A \geq \bar{A}_{\text {beruházási támogatás }}=p_{H} \frac{B}{\Delta p}-\left(p_{H} R-I\right)-S=I-\rho-S
$$


A (14)-et egyenlőséggel teljesítő $A$-ból a (13)-at egyenlőséggel teljesítő $R_{i}$-t kiszámolva és visszahelyettesítve (8)-ba látható, hogy a finanszírozó ösztönzési korlátja továbbra is automatikusan teljesül, ez (7)-ből következik. Így (14) nemcsak szükséges, de elégséges is a finanszírozáshoz. Tehát az egyösszegü, vissza nem térítendő beruházási támogatás hatására a vállalkozó kevesebb saját tőkével is el tudja indítani vállalkozását.

1. táblázat

Állami támogatási küszöbértékek beruházási támogatás esetén

\begin{tabular}{cccc}
\hline Jelölés & $\begin{array}{c}\text { Honnan } \\
\text { számítható? }\end{array}$ & Érték & \multicolumn{1}{c}{ Magyarázat } \\
\hline & & & - Ez alatt nem kap \\
& & & magánfinanszírozást a projekt, \\
& & mert nem biztosított a vállalkozó \\
& & & jó viselkedése. \\
$S$ & $(14)$ & & E fölött az államnak nem \\
& & érdemes támogatni, mert az \\
& & & csökkentené az $U$-t. \\
& & & Ennél többet nem adhat az állam \\
& & & a költségvetési korlátja miatt. \\
\hline \multirow{2}{*}{$S^{\text {max }}$} & $(10)$ & &
\end{tabular}

Forrás: szerző

Mivel $\rho>0$, ezért $\bar{S}<I-A$, vagyis az állami támogatás kisebb, mint a projekt külső tőkeszükséglete, tehát magánfinanszírozásra is szükség van. Ha az állam a társadalmi hasznosságot maximalizálja, akkor éppen $\bar{S}$ támogatást ad, se többet, se kevesebbet - feltéve, hogy az belefér a költségvetési korlátjába. A küszöbértékek lehetséges elhelyezkedését és az optimális állami támogatás nagyságát (fekete pöttyök) a 2. ábra mutatja.

2. ábra

Küszöbértékek elhelyezkedése beruházási támogatás esetén

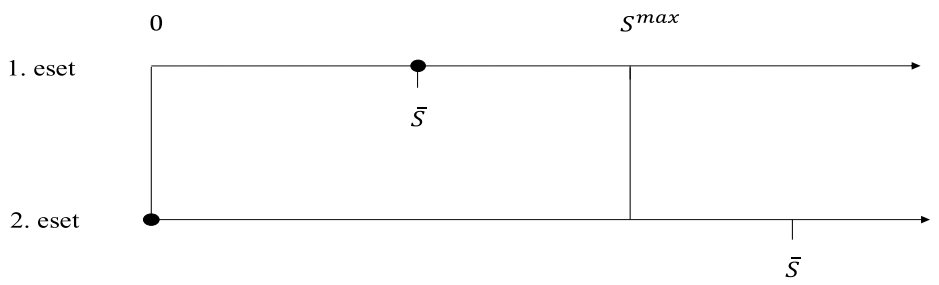

Forrás: szerző 
A 2. ábrán az 1. esetben az optimális támogatás nagysága $\bar{S}$, és a költségvetésben $E-\bar{S}$ többlet keletkezik. Az állami támogatás értéket teremt egyéni és társadalmi szinten egyaránt, mivel kipótolja a vállalkozó hiányzó tőkéjét, és így megvalósulhat a beruházás, amelyet a kockázati tőkések egyedül nem finanszíroztak volna az erkölcsi kockázat miatt.

A 2. esetben azonban a projektnek túl kevés a társadalmi haszna, így a költségvetési szempontból értelmesen adható állami támogatás túl kevés ahhoz, hogy a projekt finanszírozhatóvá váljon. Ez esetben tehát egyáltalán nem érdemes államilag támogatni a projektet, mert a magánfinanszírozó az erkölcsi kockázat miatt úgysem tudja magánfinanszírozással kipótolni a hiányzó összeget, tehát a projekt biztosan nem fog elindulni.

Az állami támogatás optimális nagysága tehát:

$S^{o p t}=\left\{\begin{array}{l}\bar{S}, \text { ha } \bar{S} \leq S^{\max } \rightarrow \text { projekt elindul } \\ 0, \text { ha } \bar{S}>S^{\max } \rightarrow \text { projekt nem indul el }\end{array}\right\}$

Eddig azt feltételeztük, hogy a vállalkozó őszintén megmondja, mekkora $A$ kezdőtőkével rendelkezik. Ha azonban a vállalkozó racionális és ismeri az állam reakciófüggvényét (15), akkor számára az az optimális stratégia, hogy csak akkora $A$-t vall be, amekkora feltétlenül szükséges, azaz annyit, ami mellett $\bar{S}=S^{\max }$, vagyis

$A^{\text {opt }}=I-\rho-E$,

ami $E>0$ esetén biztosan kisebb, mint állami támogatás nélkül, lásd (5). Megállapíthatjuk tehát, hogy optimumban (amikor mindhárom szereplő egyszerre optimalizál) az állami támogatás nagyobb lesz annál, mint ami feltétlenül szükséges lenne a projekt elindításához, a költségvetésben semmi többlet nem keletkezik $\left(E-\bar{S}=E-S^{\max }=0\right)$, így a vállalkozó kapja nem csak a projekt NPV-jét, de az összes $E$ pozitív externáliát is. Más szóval, az állami támogatás tökéletesen internalizálja az externáliát. 


\subsection{Sikerdíj}

Sikerdíj esetén a vállalkozó (2) ösztönzési korlátja megváltozik:

$p_{H}\left(R_{e}+S\right) \geq p_{L}\left(R_{e}+S\right)+B$

A finanszírozó (3) részvételi korlátja most is egyenlőséggel teljesül. (3) és (17) alapján a magánfinanszírozás szükséges feltétele:

$A \geq \bar{A}_{\text {sikerdíj }}=p_{H} \frac{B}{\Delta p}-\left(p_{H} R-I\right)-p_{H} S=I-\rho-p_{H} S$

Ismét belátható az előzőhöz hasonlóan, hogy $A=\bar{A}_{\text {sikerdij }}$ mellett a vállalkozó (8) ösztönzési korlátja is teljesül; (18) tehát szükséges és elégséges feltétele is a finanszírozásnak.

(18)-ból azt látjuk, hogy a sikerdíj várható értéke csökkenti a finanszírozáshoz szükséges $\bar{A}$ vállalkozói tőkét, így a kockázati tőkés nagyobb részt lesz hajlandó finanszírozni a beruházásból, mint sikerdíj nélkül. Az állami tőke tehát ebben a konstrukcióban nem kiszorítja a kockázati tőkét, hanem - éppen ellenkezőleg az ösztönzők javításán keresztül katalizálja azt.

2. táblázat

Állami támogatás küszöbértékek sikerdíj esetén

\begin{tabular}{|c|c|c|c|}
\hline Jelölés & $\begin{array}{c}\text { Honnan } \\
\text { számítható? }\end{array}$ & Érték & Magyarázat \\
\hline $\bar{S}$ & (18) & $\frac{(I-A)-\rho}{p_{H}}$ & $\begin{array}{l}\text { - Ez alatt nem kap } \\
\text { magánfinanszírozást a projekt, } \\
\text { mert nem biztosított a vállalkozó jó } \\
\text { viselkedése. } \\
\text { - E fölött az államnak nem érdemes } \\
\text { támogatni, mert az csökkentené az } \\
\text { U-t. }\end{array}$ \\
\hline$S^{\max }$ & (10) & $\frac{E}{p_{H}}$ & $\begin{array}{l}\text { Maximum ennyi állami támogatást } \\
\text { lehet adni a költségvetési korlát mellett } \\
\text { jó viselkedés esetén. }\end{array}$ \\
\hline
\end{tabular}

Forrás: szerző

A küszöbértékek ismét a 2. ábrán látható módon helyezkedhetnek el, így az állami támogatás optimális nagysága is (15) szerint alakul. 
Megint felmerül a kérdés, hogy mekkora $A$ saját tőkét érdemes a vállalkozónak bevallania. $\bar{S}$ képletéből látszik, hogy kisebb saját tőke esetén nagyobb állami támogatásra számíthat a vállalkozó. Ezért érdemes addig csökkentenie $A$-t, amíg $\bar{S}$ eléri a maximumát, azaz $\bar{S}=S^{\text {max }}$. A táblázatban szereplő képletek összevetéséből adódik, hogy $A^{o p t}=I-p-E$ ugyanúgy, mint beruházási támogatás esetén. Sikerdíj esetén is igaz tehát, hogy optimumban a vállalkozó kapja az NPV-t és azon felül felül az összes $E$ pozitív externáliát.

\subsection{Kimentés}

Kimentés (vagy más néven garancia) esetén az állam explicit vagy implicit módon megígéri, hogy veszteség esetén megsegíti a vállalkozót. Ez megváltoztatja a vállalkozó (2) ösztönzési korlátját az alapesethez képest:

$$
p_{H} R_{e}+\left(1-p_{H}\right) S \geq p_{L} R_{e}+B+\left(1-p_{L}\right) S
$$

A magánfinanszírozó (3) részvételi korlátja azonban változatlan formában érvényes. (20) és (3) felhasználásával a finanszírozás szükséges feltétele is átalakul, nő a vállalkozáshoz szükséges $\bar{A}$ alaptőke az alapesethez képest:

$$
A \geq \bar{A}_{\text {kimentés }}=p_{H} \frac{B}{\Delta p}-\left(p_{H} R-I\right)+p_{H} S
$$

Belátható, hogy ezúttal az $\bar{A}_{\text {kimentés }}$ nagyságú vállalkozói kezdőtőke nem biztosítja automatikusan a kockázati tőkés ösztönzését is, ez a paraméterektől (különösen a $C$-től) függ.

Megállapíthatjuk, hogy az állami garancia ellenkező irányba hat, mint a sikerdíj: rontja az ösztönzőket, így nehezíti a magánfinanszírozást és növeli a kezdeti vállalkozói tőkeigényt. (11) alapján azonban a kimentés ígérete nem teremt értéket, sőt értéket rombol, hiszen a növekvő vállalkozói tőkeigény miatt kevesebb projekt valósul meg (elveszhet az NPV és az $E$ ), ráadásul még az állami kiadásokat is növeli. Ebben a modellben tehát az állami kimentés optimális nagysága nulla.

Állami kimentési garanciát akkor sem érdemes adni, ha a vállalkozónak elég nagy kezdőtőkéje van ahhoz, hogy egyedül is elindítsa a projektet, azaz $I \geq A$, hiszen akkor ugyan nincs szükség magánfinanszírozásra, de túl magas támogatás esetén a vállalkozó ösztönzési korlátja sérülhet, vagyis csökkenhet a sikervalószínüség, ami (7) értelmében negatívvá teheti az NPV-t. A projekt mindenképpen elindul, mert a vállalkozónak van elég pénze, tehát a garanciavállalás hatására az NPV vagy nem változik, vagy csökken, az E externália biztosan nem változik, 
míg az állami kiadás biztosan nő. Tehát (11) alapján az állami kimentés ígérete még akkor is csökkenti a projekt társadalmi összhasznosságát, ha nincs szükség magánfinanszírozásra.

Összefoglalva: a modellből az látszik, hogy még jelentős pozitív externáliák sem igazolják a vállalkozónak ígért állami garanciát, hiszen az nem más, mint a vállalkozónak nyújtott, közpénzből finanszírozott ajándék, aminek legjobb esetben semmi pozitív hatása nincs, rosszabb esetben pedig kifejezetten értéket rombol.

\section{KÖVETKEZTETÉSEK}

A címben feltett kérdésre - azaz hogyan ronthatja el az állam az innovációfinanszírozást - az a válasz, hogy sokféleképpen.

Az első probléma az lehet, ha túl sokat költ az állam innovációfinanszírozásra, és ezért elhanyagol olyan területeket, ahol a piaci mechanizmusok még sokkal gyengébbek, mégis meghatározó jelentőséggel bírnak nem csak az innováció, de az egész közösség jóléte szempontjából. Ilyen területek például az oktatás és az alapkutatás.

Az allokációs nehézségek mellett procedurális problémák is felléphetnek például, ha az állam a támogatási rendszer tervezése és működtetése során nem képes vagy nem akarja a társadalmi jólétet maximalizálni. Itt hosszan lehetne elemezni a lehetséges állami kudarcokat az információs problémáktól a bürokratikus koordináció nehézségein keresztül a korrupcióig, de már önmagában az is problémás, hogyan kellene definiálni a társadalmi jólétet. A cikkben bemutatott modellekben azt feltételeztük, hogy mindhárom szereplő - a vállalkozó, a kockázati tőkés és az állam is - minden információ birtokában, világos célok mentén dönt, így pontosan ismerik egymás reakciófüggvényét is. Ha ez nem áll fenn - és a valóságban biztosan nem áll fenn -, akkor ez is kétségtelenül csökkenti a hatékonyságot. Egy további probléma az lehet - és a tanulmányban ez kapja a legtöbb figyelmet -, ha az állami támogatás elrontja a vállalkozó ösztönzőit. Beruházási támogatás és sikerdíj esetén a bemutatott modellekben ez nem fordulhatott elö. Ha magánfinanszírozásra is szükség van a projekt elindításához, akkor azért van kizárva a rossz viselkedés, mert a magánfinanszírozó csak ezzel a feltétellel lép be, tehát a magánfinanszírozás puszta tényének fegyelmező ereje van. Ha a vállalkozó egyedül finanszírozza a projektjét az állami támogatás segítségével, akkor pedig siker esetén minden haszon az övé, nem kell osztozkodnia senkivel, és feltettük, hogy jó viselkedés esetén pozitív a projekt NPV-je, egyébként negatív, ebből következik, hogy a vállalkozó ez esetben is feltétlenül motivált az erőfeszítésre. Beruházási támogatás és sikerdíj esetén tehát az állami támogatás nem rontja el az ösztönzőket, sőt a modell keretein belül kifejezetten javítja azokat. Ez egy szép példa arra, 
hogy az állam együttműködik a piaccal és kipótolja a tőkehiányt, azaz eljuttatja a projektet pontosan arra a szintre, ahonnan már be tud lépni a piaci finanszírozás. Az állami tőke tehát egyfajta katalizátorszerepet tölt be. Olyan projektek is megvalósulhatnak a segítségével, amelyeket állami támogatás nélkül a piac nem lett volna képes finanszírozni.

Jól hangzik, de sajnos, mégsem ennyire kedvező a helyzet. A beruházási támogatás és a sikerdíj lehetősége ugyanis arra ösztönzi a vállalkozókat, hogy a valóságosnál kevesebb saját tőkét valljanak be, éppen annyit, hogy a lehető legnagyobb állami támogatást tudják lehívni. Így az állam optimumban akár a teljes externáliát elköltheti a projektre, a vállalkozó pedig az NPV-n felül megkapja ezt a közpénzből finanszírozott ajándékot is. Lesz tehát számos olyan projekt, amelyet gond nélkül finanszírozott volna a piac, és az összes pozitív externália megmaradt volna a költségvetésben a közösségi célokra, de az állami támogatás lehetősége miatt a vállalkozók eltitkolják a saját tőkéjüket, és így maguknak megszerzik az externáliákat (vagy azok nagy részét). A gyakorlatban soha nem tudhatja az állam, hogy a támogatási program hatására valójában hány olyan projekt valósult meg, ami anélkül elmaradt volna és hány olyan, ami mindenképpen ugyanúgy megvalósult volna, de a vállalkozó az állami támogatás örve alatt egyszerüen csak extra járadékra (rent) tett szert. Ha az utóbbi projektek aránya nagy, akkor az innovációtámogatás összességében fölösleges pénzkidobás - még optimális támogatási konstrukció mellett is.

A bemutatott modellek kiindulópontja az volt, hogy a szereplőknek a rossz viselkedésből származó magánhasznuk ( $B$ és $C$ ) nem változik az állami támogatás hatására. Ez reális feltételezés, ha a lógásra gondolunk, hiszen a szabadidő értéke mindenképpen ugyanannyi. Ha azonban a visszaélések egyéb formáira gondolunk, akkor lehetséges, hogy az állami kontroll gyengébb, mint a magánfinanszírozó kontrollja, így állami támogatás esetén növekedhet a visszaélésekkel szerezhető magánhaszon. Sőt ez nem csak a vállalkozói oldalon léphet fel $(B)$, de a konstrukciótól függően a finanszírozói oldalon is $(C)$. Ha ez a hatás jelentős, akkor még a beruházási támogatás és a sikerdíj is ronthatja az ösztönzőket, és az összhatás negatívba csaphat át.

A modell feltételei mellett a garanciavállalás (vagy a kimentés ígérete) perverz ösztönzőként müködik, ezért a garanciavállalás kismértékben sem ajánlott még nagyon nagy pozitív externáliák mellett sem. Az állami garanciavállalás optimális nagysága tehát a modellben nulla. A valóságban elképzelhető, hogy a garanciavállalás értéket teremt, például, ha kockázatkerülő szereplőket feltételezünk és a kockázatokat piaci eszközökkel nem (vagy csak nehezen) lehet fedezni, de ekkor is figyelemmel kell lenni arra, hogy ez a konstrukció rendkívüli módon károsíthatja az ösztönzőket, és az átváltás egyáltalán nem biztos, hogy kifizetődő. 
A garanciavállalás modellje tehát bemutatja a puha költségvetési korlát jelenségét (Kornai és szerzőtársai, 2003), vagyis azt, amikor az állami kimentés ígérete megváltoztatja a magánszereplők viselkedését, és így a vállalkozó és a kockázati tőkés kevésbé küzd a projekt sikeréért. Azt azonban ebben az elméleti keretben nem tudjuk megmagyarázni, hogy az államnak mi érdeke füződhet a kimentéshez, annak tehát a modellen kívüli okai vannak. Kornai és szerzőtársai (2003) a döntések időbeli inkonzisztenciájával magyarázták meg ezt a jelenséget.

Végül megemlítjük, hogy Berlinger és szerzőtársai (2015 és 2017) folytonos beruházási modelljükben egyszeres erkölcsi kockázat mellett arra az eredményre jutottak, hogy az állami támogatás mindenképpen értéket teremt még garanciavállalás formájában is. Ott azt a következtetést vonták le, hogy a gyakorlatban megfigyelt problémák nem az állami támogatás létének, hanem főként a megvalósítási hibáknak köszönhetők. Abban a modellben az állami támogatás ismeretében a magánfinanszírozónak lehetősége nyílt a rossz támogatási formát, azaz a garanciavállalást kijavítani és átszabni sikerdíjjá. A pénzügyi közvetítőktől tehát adott esetben nemcsak a pénzáramlások és a kockázatok, de az ösztönzők transzformációját is elvárhatjuk. Ebben a cikkben azonban azt feltételeztük, hogy az állam közvetlenül a vállalkozót támogatja, és a finanszírozónak ezután már nincs módja a támogatási rendszert megváltoztatni. Ennek a mozzanatnak köszönhető, hogy most a garanciavállalás hatása kifejezetten negatív. A támogatási rendszerek megtervezésénél tehát kiemelten figyelni kell a pénzügyi közvetítőkkel való együttműködésre, beleértve az állami támogatás és a magánfinanszírozás időbeliségét is.

\section{HIVATKOZÁSOK}

Aman Sejla - Lovas Anita (2015): Információs aszimmetria kezelése a kockázati tőkés finanszírozásban: Elméleti megközelítés és a hazai tapasztalatok értékelése. Külgazdaság 59(5-6), 80-99.

Becsky Nagy Patrícia - Fazekas Balázs (2017): Résen van-e az állam? Az állami szerepvállalás hatása a kockázati tőke keresleti oldalára. Közgazdasági Szemle 64(5), 507-527., https://doi. org/10.18414/ksz.2017.5.507.

Berlinger Edina (2017): A piac és az állam szerepe az innovációban - Kornai János versus Joseph E. Stiglitz. Közgazdasági Szemle 64(4), 377-393., https://doi.org/10.18414/ksz.2017.4.377.

Berlinger Edina - Lovas Anita - Juhász Péter (2017): State subsidy and moral hazard in corporate financing. Central European Journal of Operations Research 25(4), 743-770., https:// doi.org/10.1007/s10100-016-0461-8.

Berlinger Edina - Juhász Péter - Lovas Anita (2015): Az állami támogatás hatása a projektfinanszírozásra erkölcsi kockázat és pozitív externáliák mellett: Szerződéselméleti megközelítés. Közgazdasági Szemle, 62(2), 139-171.

Csóka, P. - Havran, D. - Szücs, N. (2013): Corporate financing under moral hazard and the default risk of buyers. Central European Journal of Operations Research 22(8), p. 1-16. 
JÁKi ERIKA - MolNÁr ENdre MiháLy (2017a): Állami és uniós szerepvállalás a magvető életszakaszban lévő vállalkozások kockázatitőke-finanszírozásában. In: FARKas Beáta - PELLE ANITA (szerk.): Várakozások és gazdasági interakciók. SZTE Gazdaságtudományi Kar Közleményei (Kari konferencia, Szeged, 2016.11.24-25), Szeged: JATEPress Kiadó, 2017, 97-110. (ISBN: 978963-315-348-2).

JÁKi ERIKa - Molnár Endre Mihály (2017b): Model of the state and EU involvment in the venture capital market. In: Zoltayné Paprika Zita - Horák Péter - VÁradi Kata - Zwierczyk PÉTER TAMÁs - Vidovics Dancs Ágnes - RÁdics PÉTER JÁnos (szerk.): ECMS 2017: 31st European Conference on Modelling and Simulation. Konferencia, Budapest, 2017.05.23-2017.05.26. Nottingham: ECMS-European Council for Modelling and Simulation, 2017, p. 120-126. (ISBN:978-o9932440-4-9), https://doi.org/10.7148/2017-0120.

Jáki Erika - Molnár Endre Mihály - Walter György (2017): Government Sponsored Venture Capital: Blessing Or Curse? Management (Slovenia) 12(4), 317-331., https://doi.org/10.26493/18544231.12.

KÁLlay LÁszLó (2014): Állami támogatások és gazdasági teljesítmény. Közgazdasági Szemle 61(3), 279-298.

KarsaI, J. (2013): Venture Capital and Private Equity Industry in Hungary. Acta Oeconomica 63(1), 23-42.

KaRSAI, J. (2015): Squaring the Circle? Government as Venture Capital Investor. Studies in International Economics: Special Issue of Külgazdaság 1(1), 62-93.

KarSAI, J. (2018): Government Venture Capital in Central and Eastern Europe. Venture Capital 20(1), 73-102.

Kornai, J. - Maskin, E. - Roland, G. (2003): Understanding the soft budget constraint. Journal of Economic Literature 41(4), 1095-1136. https://doi.org/10.1257/002205103771799999.

KornaI, J. (2010): Innovation and Dynamism. Interaction between Systems and Technical Progress. Economics of Transition, 18(4), p. 629-670.

Lovas ANita (2015): A kontraszelekció veszélye és kezelése a kockázati tőkebefektetések folyamatában: A hazai befektetők tapasztalatai. Gazdaság ésPénzügy 2(2), 186-200.

Lovas ANitA - Mile BogLÁrka (2015): Az állami beavatkozás hatása a kockázati tőke-befektetésekre kettős erkölcsi kockázat mellett. Köz-Gazdaság 10(2), 87-101.

Lovas Anita, Pereczes János, RÁBA ViktóRIA (2015) Ösztönzők és korlátozások a kockázati tőkés szerződésekben. Hitelintézeti Szemle,14(3), 106-121.

Lovas ANita - NiкоLetт (2016): Akcelerátor vagy inkubátor? A hazai vállalkozásokat támogató szervezetek a nemzetközi gyakorlat tükrében. Gazdaság és Pénzügy 3(4), 305-322.

Mazzucato, M. (2012): Innovation, the state, and patient capital. In: Jacobs, M. - Mazzucato, M. (eds.) (2012): Rethinking Capitalism: Economics and Policy for Sustainable and Inclusive Growth. Chichester, UK: Wiley-Blackwell. ISBN 9781119120957.

Mazzucato, M. (szerk) Rethinking Capitalism: Economics and Policy for Sustainable and Inclusive Growth. Chichester, UK: Wiley-Blackwell. ISBN 9781119120957, https://doi.org/10.1111/1467923X.12235.

PAuly, M. (1968): The Economics of Moral Hazard: Comment. The American Economic Review 58(3), 531-537, https://doi.org/10.1017/cbo9780511528248.009.

Stiglitz, J. E. - Greenwald, B. C. (2014): Creating a Learning Society. A New Approach to Growth, Development, and Social Progress. New York, NY: Columbia University Press.

Tirole, J. (2006): Theory of Corporate Finance. Princeton, NJ: Princeton University Press. 